\title{
Measuring the Housing Market Demand Elasticity in China-Based on the Rational Price Expectation and the Provincial Panel Data
}

\author{
Mengfei Huang, Botao Lu \\ School of Economics and Management, Southwest Jiaotong University, Chengdu, China \\ Email: tmlbt1978@163.com
}

Received 4 December 2015; accepted 9 January 2016; published 15 January 2016

Copyright @ 2016 by authors and Scientific Research Publishing Inc.

This work is licensed under the Creative Commons Attribution International License (CC BY). http://creativecommons.org/licenses/by/4.0/

(c) (i) Open Access

\begin{abstract}
By using panel data of 31 provinces or cities during 1998-2012 in China, this paper measured the housing market demand elasticity. Different from the previous related research, we considered the impact of housing price expectations on housing demand and distinguished between the housing consumption demand price elasticity and investment demand price elasticity. The results showed that there were differences in different regions on housing market demand elasticity such as price elasticity of housing consumption demand, price elasticity of housing investment demand and housing demand income elasticity, etc. The results could provide useful suggestions on regulating the real estate by the Chinese government.
\end{abstract}

\section{Keywords}

Housing Price Expectations, Price Elasticity of Housing Consumption Demand, Price Elasticity of Housing Investment Demand

\section{Introduction}

Since real estate was taken as a pillar industry of the national economy, many scholars have measured the housing market demand elasticity in China. It is not a fresh topic. Comparing these studies, yet, we found that at least two aspects were questionable.

First, housing price elasticity of demand estimated by some scholars is positive, which conflicts with the basic theory of economics. The explanation given by them is that the positive housing price elasticity of demand re- 
flected the dual nature of consumption and investment of house. Such as Shen Yingzi [1], by using the data of urban households from 1995-2004 in China and single variable linear regression model, draws a conclusion that the Chinese housing price elasticity of demand of is 1.88. The result is clearly problematic. Liang Yunfang [2], by using the state space model, concludes that nearly a decade from 2002 to 2012 in China the house price elasticity of demand is positive. They think the result which is contrary to theory that price elasticity of demand is negative shows the housing has the dual nature of consumption goods and investment characteristics at the same time. Cong Ying [3] measures the national and regional housing demand elasticity in our country by using panel data of 31 provinces, municipalities and autonomous regions in China from 1999-2012. One of the conclusions is that the housing demand price elasticity in China's western provinces was 0.033 , and the author thinks that the negative demand price elasticity showed the housing of the western provinces has part of investment properties.

Second, some scholars does not consider the factors affecting housing demand such as consumer' expectation on housing price or lending rate when they construct the econometric model of housing demand. Because housing is both consumer goods and investment goods, housing demand should both include consumer demand and investment demand. The consumer' expectations on housing price and the loan interest rates are both the important factors affecting housing investment demand [4]. Wang Jinming [5] and Cong Ying [3] did not consider price expectations in the construction of real estate demand function. Gregory C. Chow [6] did not take into account the consumer' price expectations and housing loan interest rate when measuring demand elasticity of China's urban residential market.

Based on the above two points, we think the size of the elasticity of demand of housing market in China measured by these studies is questionable, because these scholars may be missing the key variable in setting the econometric model of the housing demand, which leads to the conclusion is not reliable.

Due to the two properties of housing consumption and investment, we set the econometric model of the housing demand in China and measured the housing demand elasticity which was overall, eastern, central and western with panel data including 31 regions in China from 1998 to 2013. Meanwhile, we distinguished between price elasticity of housing consumption demand and housing investment demand and analyzed the regional differences of housing demand elasticity. These results will provide beneficial advice for Chinese government to make reasonable housing policies.

\section{The Econometric Model of the Housing Demand}

Housing is both consumer goods and investment goods, so housing demand includes consumer demand and investment demand. The main factors influencing the consumer demand are the current housing price, income and population scale. The influencing factors of housing investment demand are mainly price expectations and housing loan interest rates. Kuang Weida [4] considered the effect of housing price expectations and thought only when speculators expected next home prices rising, they would like to speculation. He assumed that the housing consumer demand decreased with the current housing price rising and housing investment demand increased with the future housing price increasing. Due to hard to distinguish between the investment and speculation, we adopt the same method as Kuang Weida [4] which did not make the distinction between both.

About the relation between population scale and the housing market demand, scholars generally believe that it is a positive correlation, but Zhu Jiajie and Lou Huaxiang [7] thought that the relation between population size and housing construction area appeared inverted $U$ shape which showed that in a certain scope the growth of the population would promote housing area, but beyond a certain level, due to urban resources and environment constraints problems, per capita housing area tend to decline. This article intends to adopt this research conclusion to build econometric model of housing demand and make an empirical test on the conclusion.

Consumers' expectation forms on housing price mainly include static forecast, adaptive expectation and rational expectation. In this paper, according to Robert E. Lucas [8], we assumed rational expectation was consumers' expectation form. Because it is very difficult to measure the rational expectations, based on the general processing method, we express the real average house prices of next period as the consumer' current rational expectations for housing price. According to the above description, we finally built the econometric model of housing demand:

$$
Q_{i t}=\alpha_{i}+\alpha_{1} p_{i t}+\alpha_{2} p_{i, t+1}+\alpha_{3} y_{i t}+\alpha_{4} r_{i t}+\alpha_{5} l_{i t}+\alpha_{6} l_{i t}^{2}+\mu_{i t}
$$

where $Q_{i t}$ is housing demand represented with housing sales area of each region, $p_{i t}$ and $p_{i, t+1}$ are current average sales price of housing and that of next year respectively, $y_{i t}$ is GDP of each regions and $r_{i t}$ is loans 
for five years and above $l_{i t}$ is the size of resident population in each region, $\mu_{i t}$ is random error terms. According to the related theory above, we assumed $\alpha_{1}<0, \alpha_{2}>0, \alpha_{3}>0, \alpha_{4}<0, \alpha_{6}<0$. Because housing demand can be divided into consumption demand and investment demand, we defined $\alpha_{1}$ as price elasticity of housing consumption demand and $\alpha_{2}$ as price elasticity of housing investment demand.

\section{Date and Model Estimation}

Based on available data as well as China's housing system reform which began in 1998, we select the panel data including 31 regions from 1998-2012 except the price data of rational expectations in 2013. All the data except lending rates are derived from the China statistical yearbook. Due to consumers' long time for housing loans, we adopted the loans rate for more than 5 years from the people's bank of China website (http://www.pbc.gov.cn/). In order to eliminate the effects of inflation, we processed GDP data and housing prices data with CPI in 1978 as a benchmark and the normal mortgage rates are translated into real mortgage rates. Finally, in order to reduce or eliminate the heteroscedasticity of data, we took the logarithm for each variable except mortgage rates. Descriptive statistics of variables are shown in Table 1.

In order to avoid spurious regression, we deal variables with the unit root test and co-integration test. For the unit root test, LLC (Levin-Lin-Chu), IPS (Im-Pesaran-Shin) and Fisher-ADF test were adopted and the results showed that all the sequences were integrated of order 1. For co-integration test, we adopted Kao test and the result showed that there was a co-integration relationship between variables. Due to limited space, we did not report the specific test results. Eviews 7.0 was used here and the final estimates of housing demand equation were showed in Table 2.

The following conclusions can be found from Table 2:

1) The results of Hausman test showed that the fixed effects model applied to the overall, the eastern and the central regions in China but the random effects model applied to the western region. According to the value of adjusted $\mathrm{R}^{2}$, all models above fit the sample data well. Several coefficients in the central model were not significant statistically, but coefficients in other model were significant statistically. Meanwhile, the symbols of all coefficients were consistent with theoretical assumptions.

2) As a whole, China's price elasticity of housing consumption demand was 0.594 greater than the price elasticity of housing investment demand 0.326, which showed that during the period 1998-2013 the housing consumer demand was dominated and the housing investment demand was significant and should not be ignored. The price elasticity of housing consumption demand here was consistent with the value 0.5 to 0.6 provided by Gregory C. Chow but beyond the value 0.484 showed by Cong yin.

The price elasticity of housing consumption demand in eastern, central and western provinces was -0.706 , -0.066 and -0.708 respectively, which showed that the housing consumption demand in these region were rigid and the price elasticity of housing consumption demand in central provinces was far lower than that of the eastern and western regions.

The price elasticity of housing investment demand in eastern, central and western provinces was $0.511,0.222$ and 0.321 respectively, but the value 0.222 and 0.321 were not significant statistically, which showed that in the eastern region housing investment behavior were strong and reflected the fact that in the eastern region the housing price was the highest and rose rapidly. Though housing investment behavior emerged in the central and

Table 1. Descriptive statistics of variables.

\begin{tabular}{ccccc}
\hline Variables & Unit & Mean & Max & Min \\
\hline $\ln Q_{i t}$ & Thousands of square meters & 6.8385 & 9.2348 & 0.3364 \\
$\ln p_{i t}$ & Yuan/square metre & 6.2740 & 8.1067 & 5.1342 \\
$\ln p_{i, t+1}$ & Yuan/square metre & 6.3641 & 8.1392 & 5.2313 \\
$\ln y_{i t}$ & One hundred million yuan & 6.8469 & 9.1946 & 3.0383 \\
$r_{i t}$ & \% & 4.7320 & 9.9800 & 1.1460 \\
$\ln l_{i t}$ & Ten thousand people & 8.0472 & 9.2680 & 5.4070 \\
\hline
\end{tabular}


Table 2. Regression results.

\begin{tabular}{|c|c|c|c|c|}
\hline & Overall & Eastern & Central & Western \\
\hline Variables & Fixed effects & Fixed effects & Fixed effects & Random effects \\
\hline $\mathrm{C}$ & $\begin{array}{c}1.39 \\
(0.16)\end{array}$ & $\begin{array}{l}1.151 \\
(0.14)\end{array}$ & $\begin{array}{l}86.506 \\
(0.63)\end{array}$ & $\begin{array}{l}-3.917 \\
(-0.41)\end{array}$ \\
\hline $\ln p_{i t}$ & $\begin{array}{c}-0.594^{* * *} \\
(-3.65)\end{array}$ & $\begin{array}{c}-0.706^{* * *} \\
(-2.69)\end{array}$ & $\begin{array}{l}-0.066 \\
(-0.22)\end{array}$ & $\begin{array}{c}-0.708^{* * *} \\
(-2.40)\end{array}$ \\
\hline $\ln p_{i, t+1}$ & $\begin{array}{l}0.326^{* *} \\
(1.98)\end{array}$ & $\begin{array}{l}0.511^{* *} \\
(1.94)\end{array}$ & $\begin{array}{l}0.222 \\
(0.75)\end{array}$ & $\begin{array}{l}0.321 \\
(1.05)\end{array}$ \\
\hline $\ln y_{i t}$ & $\begin{array}{r}1.636^{* * * *} \\
(18.60)\end{array}$ & $\begin{array}{l}1.816^{* * *} \\
(12.91)\end{array}$ & $\begin{array}{c}1.394^{* * *} \\
(8.08)\end{array}$ & $\begin{array}{c}1.545^{* * *} \\
(7.23)\end{array}$ \\
\hline$r_{i t}$ & $\begin{array}{c}-0.035^{* * *} \\
(-4.41)\end{array}$ & $\begin{array}{l}-0.021^{*} \\
(-1.63)\end{array}$ & $\begin{array}{c}-0.046^{* * *} \\
(-4.21)\end{array}$ & $\begin{array}{c}-0.043^{* * *} \\
(-2.68)\end{array}$ \\
\hline $\ln l_{i t}$ & $\begin{array}{c}1.99 \\
(0.90)\end{array}$ & $\begin{array}{l}2.877 \\
(1.04)\end{array}$ & $\begin{array}{c}-17.477 \\
(-0.53)\end{array}$ & $\begin{array}{l}1.145 \\
(0.44)\end{array}$ \\
\hline$\left(\operatorname{lnl} l_{i t}\right)^{2}$ & $\begin{array}{c}-0.305^{* *} \\
(-2.13)\end{array}$ & $\begin{array}{c}-0.441^{* *} \\
(-2.43)\end{array}$ & $\begin{array}{l}0.802 \\
(0.41)\end{array}$ & $\begin{array}{l}-0.092 \\
(-0.53)\end{array}$ \\
\hline Adjusted $R^{2}$ & 0.955 & 0.943 & 0.948 & 0.865 \\
\hline F-statistic & $275.252^{* * *}$ & $158.555^{* * *}$ & $108.792^{* * *}$ & $160.395^{* * *}$ \\
\hline Hausman test & Chi-Sq (5) $=62.46^{* * *}$ & Chi-Sq (5) $=74.57^{* *}$ & Chi-Sq $(6)=12.31^{* *}$ & Chi-Sq (6) $=0.000$ \\
\hline Observation & 465 & 180 & 135 & 150 \\
\hline
\end{tabular}

Note: the numbers in brackets are the values of "t" statistic and ${ }^{*},{ }^{* *},{ }^{* * *}$ are the significance level of $0.1,0.05$ and 0.01 respectively. The eastern includes: Peking, Fujian, Guangdong, Guangxi, Hainan, Hebei, Jiangsu, Liaoning, Shandong, Shanghai, Tianjin, Zhejiang. The central includes: Anhui, Henan, Heilongjiang, Hubei, Hunan, Jilin, Jiangxi, Inner Mongolia, Shanxi. The western includes: Gansu, Guizhou, Ningxia, Qinghai, Shanxi, Sichuan, Xizang, Xinjiang, Yunnan, Chongqing.

western provinces, the conclusion was not supported statistically.

3) Nationwide, the overall income elasticity of the housing demand is 1.636 which is full of elasticity. The value 1.636 is beyond the result provided by Gregory C. Chow and Cong Ying where the value was about 1 and 1.105 respectively. Seeing from each region, all the income elasticity of housing demand are beyond 1 and full of elasticity, which showed that as income increases the consumers prefer taking housing investment as an important way to accumulate household wealth. This kind of phenomenon may be caused by too little investment channels in China.

4) The overall rate elasticity of housing demand was 0.035 , and that in the eastern, the central and the western is $-0.021,-0.046$ and -0.043 respectively, which reflect that the influence which the five-year loan interest rates impact on the housing demand is significantly negative and the results consistent with the theoretical expectations.

5) About the effect of population size on housing demand, the results in the overall and the eastern model verified the Zhu Jiajie and Lou Huaxiang, namely, the relation between population size and housing construction area appeared inverted U shape. According to present China's condition of regional economic development, the eastern region takes the leading position and resources and environment constraints become a serious problem for its sustainable development. In the central model and the western model, the estimated results did not statistically support Zhu Jiajie, Lou Huaxiang. The reason may be that the resources and environment constraints in the two regions are nothing serious in present stage of economic development.

\section{Conclusions}

Through the empirical analysis above, this paper draws the following conclusions:

1) In this paper, from a macro point of view, on the basis of comprehensively considering the factors affecting housing demand, the price elasticity of housing consumer demand we measured is negative and the elasticity of housing investment demand is positive, which suggests that the rise in the current price of housing will cause a decline in present housing demand and the rise in next expected price will cause the rise in the present housing 
demand. This conclusion accords with the demand theory. We think the estimated results in our model are better than those of the econometric model where some important explanatory variables are missed.

2) The price elasticity of housing investment demand in the eastern is 0.511 , which is larger than other two regions and is statistically significant. The conclusion accords with the viewpoint that many scholars believe that at present there exist high housing price and serious real estate bubble in many cities in China, such as Shenzhen, Beijing, Shanghai, Hangzhou, etc. Exactly, these cities locate in the eastern region in China. They attribute it to enormous housing speculative demand. At present, in views of the high housing price and serious real estate bubble in many areas, the Chinese government has adopted comprehensive real estate policies to suppress the housing investment demand. The conclusion provided by this paper shows that in the eastern region there is remarkable housing investment behavior but in the central region and the western region the housing investment behavior is statistically insignificant, so the policy to suppress the housing investment demand should focus on the eastern region.

\section{Funding}

This paper is sponsored by National Natural Science Foundation of China (NSFC) and the name of the project is An Application Research on Micro Econometric Analysis and Measurement of Urban Housing Consumption and Investment Demand in China. The item number is 71171169.

\section{References}

[1] Shen, Y.Z. (2007) Analysis of Housing Consumption Demand Elasticityabout China's Urban Residents. Economics and Management, No. 3, 78-80.

[2] Liang, Y.F. and Gao, T.M. (2006) An Empirical Analysis of the Cause on The Fluctuations in Commodity Housing Sales Price in China. Management World, No. 8, 54-56.

[3] Cong, Y. (2014) Regional Differences in Housing Demand Elasticity in China—Based on The Empirical Analysis of Provincial Panel Model. Price Theory and the Practice, No. 3, 62-63.

[4] Kuang, W.D. (2010) Expectation, Speculation and Urban Housing Price Volatility in China. Economic Research, No. 9, 69.

[5] Wang, J.M. and Gao, T.M. (2004) Dynamic Analysis of Supply and Demand Function in Chinese Real Estate Market. China Soft Science, No. 4, 90-92.

[6] Chow, G.C. and Niu, L.L. (2010) Housing Demand and Supply of Urban Residents in China. Journal of Financial Research, No. 1, 36-38.

[7] Zhu, J.J., Lu, H.X., Zheng, S.Q. and Li, L. (2014) Analysis of Urban Housing Demand: Method, Data and Model. The City Planning, No. 38, 147.

[8] Lucas Jr., R.E. (1972) Expectations and the Neutrality of Money. Journal of Economic Theory, 4, 103-124. http://dx.doi.org/10.1016/0022-0531(72)90142-1 